Limited access to health care and education increases the risk of adults with hypertension developing cognitive impairment and dementia, partly due to insufficient levels of antihypertensive treatment. ${ }^{5}$

To prevent increase in cognitive impairment and dementia, physicians and politicians should not only improve treatment of hypertension and diabetes during adult life, but also consider risk factors earlier in life that may predispose adults to cognitive impairment. ${ }^{7,8}$

(C) 2015 American Academy of Neurology

1. Muller M, Sigurdsson S, Kjartansson O, et al. Joint effect of mid- and late-life blood pressure on the brain: the AGESReykjavik Study. Neurology 2014;82:2187-2195.

2. Roberts RO, Knopman DS, Przybelski SA, et al. Association of type 2 diabetes with brain atrophy and cognitive impairment. Neurology 2014;82:1132-1141.

3. Sosa AL, Albanese E, Stephan BC, et al. Prevalence, distribution, and impact of mild cognitive impairment in Latin America, China, and India: a 10/66 population-based study. PLoS Med 2012;9:e1001170.
4. He W, Muenchrath M, Kowal P. Shades of Gray: A CrossCountry Study of Health and Well-Being of the Older Populations in SAGE Countries, 2007-2010. Washington, DC: US Government Printing Office; 2012. Available at: http://www.census.gov/content/dam/Census/library/ publications/2012/demo/p95-12-01.pdf. Accessed July 10, 2014.

5. Lloyd-Sherlock P, Beard J, Minicuci N, Ebhrahim S, Chatterji S. Hypertension among older adults in low- and middle-income countries: prevalence, awareness and control. Int J Epidemiol 2014;43:116-128.

6. Launer LJ, Hughes T, Yu B, et al. Lowering midlife levels of systolic blood pressure as a public health strategy to reduce late-life dementia: perspective from the Honolulu Heart Program/Honolulu Asia Aging Study. Hypertension 2010; 55:1352-1359.

7. Whalley LJ, Dick FD, McNeill G. A life-course approach to the aetiology of late-onset dementias. Lancet Neurol 2006; 5:87-96.

8. Muller M, Sigurdsson S, Kjartansson O, et al. Birth size and brain function 75 years later: the population-based Age Gene/Environment Susceptibility-Reykjavik Study. Pediatrics 2014;134:761-770.

\title{
CORRECTION
}

\section{Influence of hospital-level practices on readmission after ischemic stroke}

In the article "Influence of hospital-level practices on readmission after ischemic stroke" by J.F. Burke et al. (Neurology ${ }^{\circledR}$ 2014;82:2196-2204), there is an error in table 2. The authors erroneously reported small cell sizes, which is a violation of the data use agreement of the analyzed dataset, the State Inpatient Databases. Under "Charlson comorbidities," the 10th row (AIDS), second column (Readmission) should read " $<10(0.0)$." Under "LSTs," all 3 columns in the eighth row (Ventriculostomy) should read " $<10(0.0)$." The intent of the small cell data use restrictions is to minimize the risk of identifying individuals; the authors are confident that nothing in their paper could be used to identify individuals or their personal information. This does not influence the accuracy of the manuscript's primary findings or conclusions. The authors regret the error. 


\section{Neurology}

\section{Influence of hospital-level practices on readmission after ischemic stroke Neurology 2015;84;330 \\ DOI 10.1212/WNL.0000000000001198}

This information is current as of January 19, 2015

\section{Updated Information \&} Services

Permissions \& Licensing

Reprints including high resolution figures, can be found at: http://n.neurology.org/content/84/3/330.full

Information about reproducing this article in parts (figures,tables) or in its entirety can be found online at:

http://www.neurology.org/about/about_the_journal\#permissions

Information about ordering reprints can be found online:

http://n.neurology.org/subscribers/advertise

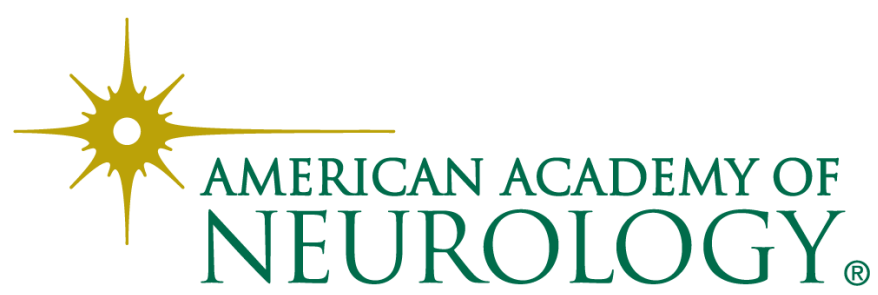

